\title{
Malnutrition and excess weight in children and adolescents: a review of Brazilian studies
}

\author{
Desnutrição e excesso de peso em crianças e adolescentes: uma revisão de estudos brasileiros \\ Desnutrición y exceso de peso en niños y adolescentes: una revisión de estudios brasileños
}

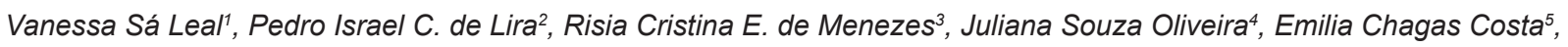

Sonia Lúcia L. S. de Andrade ${ }^{6}$

\section{ABSTRACT}

Objective: To review the Brazilian literature addressing the prevalence and factors associated with height deficit and overweight in children and adolescents aged five to 19 years-old.

Data source: The search was carried out in the PubMed and Bireme databases using the following descriptors: "malnutrition”, "height deficit”, "obesity”, "overweight", "BMI”, “children”, "student”, "adolescent” and "Brazil”. The following inclusion criteria were adopted: population-based original paper; evaluation of associated factors with statistical regression analysis; and articles that were published from 2000 to 2010.

Synthesis of data: Only two studies met the established criteria concerning height deficit, and the frequency varied from 3.5 to $16.7 \%$; the social status and the education appear as associated factors. Of the 12 studies investigating overweight, $67 \%$ were conducted in Southern Brazil, and none included the North of the country. Most were crosssectional studies. The prevalence varied from 13.9 to $38.9 \%$ and the main associated factors were socioeconomic level, family influence, and sedentary lifestyle.
Conclusions: The association of income and educational level with both height deficit and overweight, even though with opposite trends, draws attention. Further studies, especially in the North and Northeast of Brazil, are suggested.

Key-words: malnutrition; overweight; obesity; children; adolescents; determinants.

\section{RESUMO}

Objetivo: Revisar a literatura brasileira sobre a prevalência e os fatores associados ao déficit de estatura e ao excesso de peso em crianças e adolescentes de cinco a 19 anos.

Fontes de dados: A pesquisa foi realizada nas bases de dados PubMed e Bireme, utilizando-se os seguintes descritores: “desnutrição”, "déficit estatural”, “obesidade”, "sobrepeso”, “IMC”, “criança”, “escolar”, “adolescente” e "Brasil”. Foram considerados os seguintes critérios de seleção: artigo original de base populacional, avaliação dos fatores associados por meio de análise estatística de regressão, e artigos publicados entre 2000 e 2010.

Síntese dos dados: No que se refere ao déficit estatural, apenas dois estudos atenderam aos critérios estabelecidos,
Instituição: Universidade Federal de Pernambuco (UFPE) e Centro Acadêmico de Vitória, Vitória de Santo Antão, PE, Brasil

${ }^{1}$ Doutorado em Nutrição em Saúde Pública pela UFPE; Professora-Adjunta do Curso de Nutrição do Centro Acadêmico de Vitória da UFPE e da Faculdade de Nutrição da Ufal, Maceió, AL, Brasil

${ }^{2}$ Doutorado em Medicina pela London School of Hygiene and Tropical Medicine, Inglaterra; Professor Titular do Departamento de Nutrição da UFPE, Recife, PE, Brasil

${ }^{3}$ Doutorado em Nutrição em Saúde Pública pela UFPE; Professora Adjunta da Faculdade de Nutrição da Ufal, Maceió, AL, Brasil

${ }^{4}$ Doutorado em Nutrição em Saúde Pública pela UFPE; Professora Adjunta do Curso de Nutrição do Centro Acadêmico de Vitória da UFPE, Vitória de Santo Antão, PE, Brasil

${ }^{5}$ Mestrado em Nutrição em Saúde Pública pela UFPE; Professora-Assistente da Faculdade de Nutrição da Ufal, Maceió, AL, Brasil

${ }^{6}$ Doutorado em Nutrição em Saúde Pública pela UFPE; Professora Adjunta do Departamento de Nutrição da UFPE, Recife, PE, Brasil
Endereço para correspondência:

Vanessa Sá Leal

Avenida Afonso Olindense, 344 - casa 26 - Várzea

CEP 50810000 - Recife/PE

E-mail: vanessasaleal@yahoo.com.br

Conflito de interesse: nada a declarar

Recebido em: 21/6/2011

Aprovado em: 16/11/2011 
apresentando variações de 3,5 a 16,7\%, com indicação da condição social e da escolaridade dos jovens como fatores associados. Dos 12 estudos que investigaram o excesso de peso, $67 \%$ foram realizados na região Sul do Brasil e nenhum incluiu o Norte do país. A maioria apresentou delineamento transversal. As prevalências variaram de 13,9 a 38,9\%, sendo os principais fatores associados: padrões socioeconômicos, influência familiar e estilo de vida sedentário.

Conclusões: As associações das variáveis renda e nível de escolaridade com o déficit de estatura e com o sobrepeso, embora com tendências opostas, chamam a atenção. Sugere-se a realização de mais estudos, em especial nas regiões Norte e Nordeste do Brasil.

Palavras-chave: desnutrição; sobrepeso; obesidade; crianças; adolescentes; determinantes.

\section{RESUMEN}

Objetivo: Revisar la literatura brasileña de 2001 a 2010 sobre las prevalencias y los factores asociados al déficit de estatura y al exceso de peso en niños y adolescentes de cinco a 19 años.

Fuentes de datos: La investigación fue realizada en las bases de datos Pubmed y Bireme, utilizándose los descriptores a continuación: «desnutrición», «déficit estatural», «obesidad», «sobrepeso», «IMC», «niño», «escolar», «adolescente», «Brasil»y «determinantes». Se consideraron los siguientes criterios de selección: artículo original de base poblacional, evaluación de los factores asociados, por medio de análisis estadístico de regresión, y artículos publicados entre 2000 y 2009.

Síntesis de los datos: En lo que se refiere al déficit estatural, solamente dos estudios atendieron a los criterios establecidos, presentando variaciones de 3,5 a 16,7\%, e indicación de la condición social y de la escolaridad de los jóvenes como factores asociados. De los 12 estudios que investigaron el exceso de peso, 66,6\% fueron realizados en la región Sur de Brasil y ninguno incluyó al Norte del país. La mayoría presentó delineación transversal. Las prevalencias variaron de 13,9 a $38,9 \%$, siendo los principales factores asociados: estándares socioeconómicos, influencia familiar y estilo de vida sedentario.

Conclusiones: Las asociaciones de las variables ingresos y nivel de escolaridad con el déficit de estatura y el sobrepeso, aunque con tendencias opuestas, llaman la atención. Se sugiere la realización de más estudios, en especial en las regiones Norte y Nordeste de Brasil.
Palabras clave: desnutrición; sobrepeso; obesidad; niños; adolescentes; determinantes.

\section{Introduction}

The intense demographic and technological changes that have been taking place since the second half of the twentieth century have led to changes in the dietary intakes and lifestyles of populations in many different countries, particularly those that have been in development, like Brazil ${ }^{(1)}$. These changes are indicative of the process of nutritional transition, illustrated by disorders that, at one end of the scale, are caused by infectious diseases and deficiency processes, such as energy-protein malnutrition, vitamin A deficiency and anemia, while at the other end of the scale are diseases of modernity caused by nontransmissible chronic processes, including diabetes mellitus, obesity, arterial hypertension and many different types of neoplasm ${ }^{(2)}$.

Malnutrition is manifest as stunting in childhood and adolescence and is attributable to a series of factors that are intimately related to living conditions and the ability to meet basic needs, such as access to food, basic sanitation, healthcare and good quality education ${ }^{(3)}$. In less developed countries, thousands of children do not fulfill their full growth potential, with consequences for academic performance and transference of poverty to succeeding generations ${ }^{(4)}$.

Studies of the nutritional status of the Brazilian population conducted from 1974 to 2006 indicate that there has been a reduction of approximately $80 \%$ in malnutrition among children under 5 , although there are major differences between the country's five administrative regions and the worst situations are in the North and Northeast regions ${ }^{(5)}$. For children aged 5 to 9 , the same trend was observed as with the under- 5 s (with approximately a $6.8 \%$ prevalence of stunting). The prevalence among adolescents is higher however $(9.8 \%)$, but there are no data from which to gauge the trend over recent decades ${ }^{(6,7)}$.

Over a similar period, nutritional transition has been manifest in the rates of excess body weight among the young increasing by three to four times between 1974 and 2009, to the point where $47.8 \%$ of children and $21.5 \%$ of adolescents in Brazil are overweight or obese ${ }^{(6)}$. Segundo Miech et al ${ }^{(8)}$, the earlier and the more intensely that obesity develops, the greater the risks of obesity continuing into adulthood and of its related comorbidities emerging. In general, the immediate determinants of obesity are a hypercaloric diet, rich in trans fats and saturated fatty acids, excessive sugar consumption 
and inactivity, as well as other unhealthy habits that are part of Western lifestyles ${ }^{(9)}$. In addition to behavioral factors, previous nutritional states, such as fetal malnutrition, and socioeconomic and environmental characteristics also have an impact on overweight ${ }^{(10)}$.

The consensus recognition that growth and nutritional status should be monitored during the critical first years of life has led to countless clinical and epidemiological studies being conducted with the under- 5 s. In contrast, few studies have investigated nutritional disorders (malnutrition and obesity) among schoolchildren and adolescents, describing their characteristics and associated factors. In response to this, this literature review was conducted to provide an overview of the prevalence rates and factors associated with stunting and excess weight among children and adolescents aged 5 to 19 years, on the basis of the results of studies representative of Brazil's different administrative regions.

\section{Methods}

The literature review was conducted from June to December, 2010. Searches were run on Pubmed and Bireme databases using the following descriptors (in both Portuguese and English): "malnutrition", "stunting”, "obesity”, "overweight”, "BMI”, “children”, "student”, “adolescent", "determinants" and "Brazil" (this last to identify articles relating to the Brazilian population).

Articles were selected if they met the following criteria: probabilistic sample of Brazilian children and adolescents (five to 19 years); original population-based article providing information on methodological procedures (sample selection and representativeness); determinants calculated using statistical regression analysis and data collection from 2000 onwards.
The lack of studies reporting on stunting during the chosen period prompted a decision to accept articles published between 2001 and 2010, irrespective of year of data collection. Nevertheless, just two of the 29 articles identified in the databases met the criteria described above. The search identified 56 articles dealing with excess weight in the age group of interest and within the correct period. However, just 12 met the remaining inclusion criteria.

\section{Results}

Laurentino et $a l^{(11)}$ conducted a cross-sectional study of stunting that was representative of the state of Pernambuco and reported prevalence of $16.7 \%$ in 1997 , stating that explanatory variables for stunting included living in a rural area, male sex, drinking untreated water, per capita income below one quarter of the minimum monthly wage and inadequate educational level. Vieira $e t$ al ${ }^{(12)}$ studied schoolchildren in the city of Pelotas, Rio Grande do Sul, in 2004. They found that 3.5\% of children and adolescents had growth deficit and detected a strong association with educational level, in addition to age (Chart 1).

The majority of the 12 studies dealing with excess weight were cross-sectional, but there was one cohort study and one case-control study. The research data were collected between 2000 and 2007 and the great majority of studies were on the municipal level, although one was representative to the state level ${ }^{(13)}$. All had probabilistic samples, $75 \%$ recruited schoolchildren and $25 \%$ used population-based sampling frames. Sample sizes varied from 719 to 28,084 children and adolescents and age ranged from six to 19 years. Two-thirds of these studies $(\mathrm{n}=8)^{(12,14-20)}$ were conducted in Brazil's South region, with

Chart 1 - Characteristics of Brazilian studies addressing prevalence rates (\%) and factors associated with stunting in children and adolescents aged five to 19. Brazil, 2001 to 2010

\begin{tabular}{|c|c|c|c|c|c|c|c|}
\hline References & Study design & Population & $\begin{array}{c}\text { Sample } \\
\text { (n) }\end{array}$ & Location & $\begin{array}{c}\text { Year of data } \\
\text { collection }\end{array}$ & $\%$ & $\begin{array}{c}\text { Associated } \\
\text { factors }\end{array}$ \\
\hline $\begin{array}{l}\text { Vieira } \\
\text { et a/ }{ }^{(12)}\end{array}$ & Cross-sectional & $\begin{array}{l}\text { Seven to 12-year-old: } \\
\text { schoolchildren from public } \\
\text { and private schools. }\end{array}$ & 28,084 & Pelotas, RS & 2004 & 3.5 & $\begin{array}{c}\uparrow \text { Age; } \\
\downarrow \text { educational level. }\end{array}$ \\
\hline $\begin{array}{l}\text { Laurentino } \\
\text { et a/(11) }\end{array}$ & Cross-sectional & Six to 12 -year-olds. & 894 & $\begin{array}{l}\text { Pernambuco, } \\
\text { PE }\end{array}$ & 1997 & 16.7 & $\begin{array}{c}\text { Rural Interior; } \\
\text { male sex; } \\
\text { leducational level; } \\
\text { untreated water; } \\
\text { Income < } 0.25 \\
\text { minimum wage. }\end{array}$ \\
\hline
\end{tabular}


Chart 2 - Characteristics of Brazilian studies addressing prevalence rates (\%) and factors associated with excess weight in children and adolescents aged five to 19. Brazil, 2001 to 2010

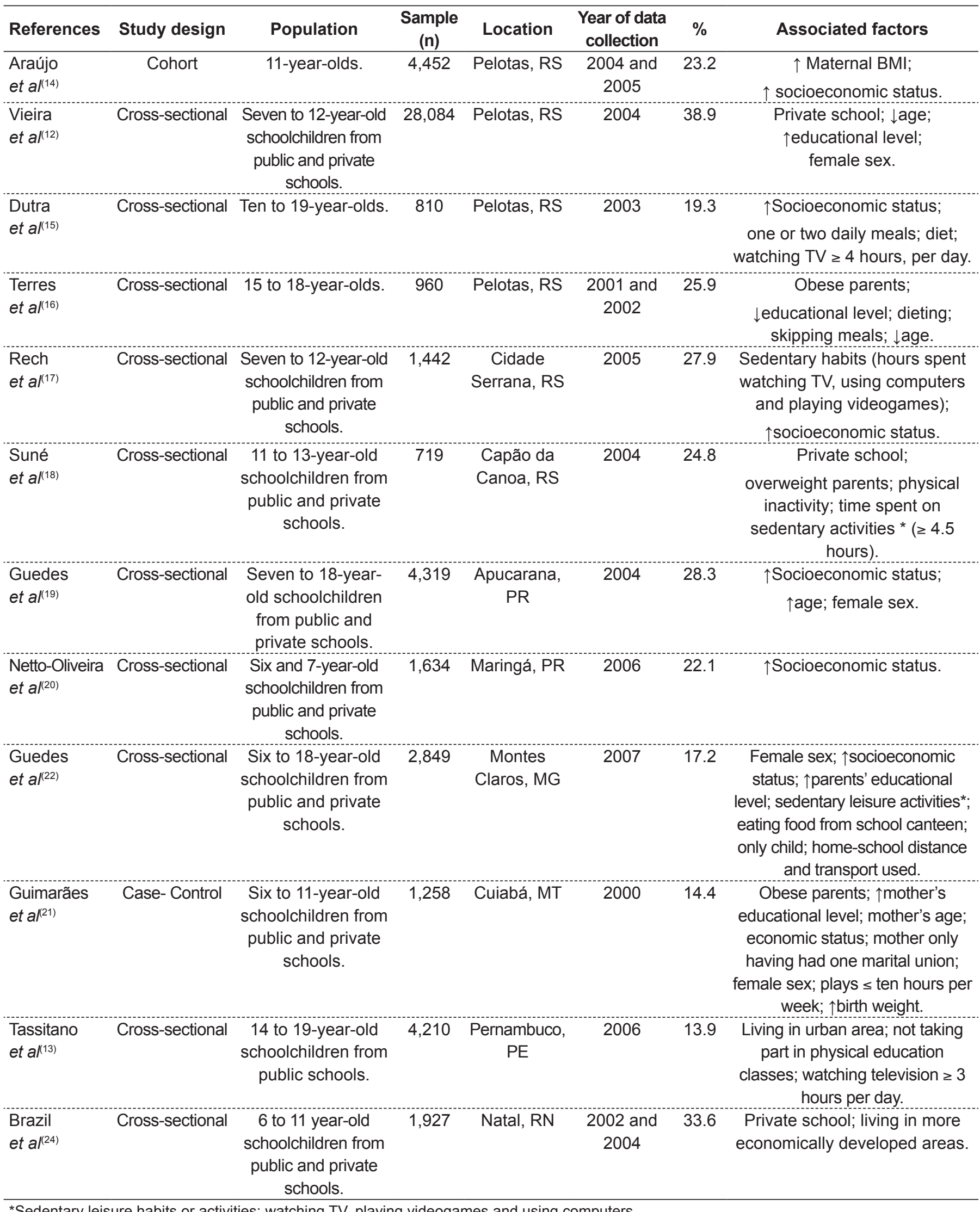

\footnotetext{
*Sedentary leisure habits or activities: watching TV, playing videogames and using computers
} 
the city of Pelotas, in Rio Grande do Sul, standing out for hosting five of these studies. In contrast with the South, it is notable that there were no publications investigating the North region (Chart 2).

Prevalence rates for excess weight varied from 13.9 to $38.9 \%$ and two-thirds of the studies $(\mathrm{n}=8)$ reported rates over $20 \%$. All of the studies investigated the relationship between excess weight and the variable sex, and $33 \%$ found a significant association, all of which stated excess weight was more likely among females ${ }^{(12,19,21)}$. Age was related to excess weight in three studies ${ }^{(12,16,19)}$, inversely so in two of them (Chart 2).

A number of studies investigated whether parents' had excessive body mass index (BMI) and all of those that analyzed this variable found it had a positive association with overweight children and adolescents ${ }^{(14,16,18,21)}$. The case-control study conducted by Guimarães $e t$ al $l^{(21)}$ demonstrated that, in addition to mother's educational level, parents' socioeconomic status and BMI, elevated birth weight, children whose mothers were in a stable relationship (only one marital union) and children with no siblings were twice as likely to be overweight. Guedes et $a l^{(22)}$ studied schoolchildren and also found a positive association between increased risk of overweight and being an only child or having up to two siblings (Chart 2).

With regard to behavioral determinants, half of the studies analyzed found an association between excess weight and sedentary practices. Watching television, playing videogames or using computers for several hours per day $(>3)$ were the variables that most often exhibited associations ${ }^{(15,17,18,22)}$. Physical inactivity or not taking part in physical education at school also had a significant relationship with excess weight $^{(13,18,21)}$. Unhealthy diets and the habit of skipping daily meals were listed as determinants in two studies ${ }^{(15,16)}$. According to Guedes et al ${ }^{(22)}$, the distance between home and school, the means of transport used (car or public transport) and eating food from the school cafeteria were also associated with excess body weight (Chart 2).

Eight studies investigated socioeconomic status, most of them using the classification criteria established by the Brazilian Association of Market Research Companies (ABEP - Associação Brasileira de Empresas de Pesquisa) ${ }^{(23)}$ or similar, and seven detected associations with excess weight ${ }^{(14,15,17,19-22)}$. Studies that did not analyze ABEP or similar socioeconomic criteria ( $n=4)$ found a positive relationship between overweight and living in an urban area ${ }^{(13)}$ or in areas with a greater degree of economic development ${ }^{(24)}$ and also with attending private school $^{(12,18)}$.
Mother's or father's educational level had a direct and significant association in two studies ${ }^{(22,24)}$ (Chart 2).

\section{Comments}

In view of the growing prevalence of excess weight in childhood and adolescence and, in parallel, the reduction in malnutrition observed over the years, studies of malnutrition appear to be being conducted less frequently. However, it is important not to forget that the prevalence of the stunting identified for the whole of Brazil $(6.7 \%$, in children and $9.8 \%$ in adolescents $)^{(6,7)}$ and for Pernambuco state $(16.7 \%)^{(11)}$ still classify this disorder as a public health problem, and one that is undoubtedly related to the effects of the perverse sanitary and socioeconomic conditions to which a large part of the population are subjected, particularly those less than 18 years old ${ }^{(5,25)}$.

Vieira $e t a l^{(12)}$ conducted a study in the city of Pelotas, which has a high Human Development Index, but despite this they still observed that, although prevalence was low (3.5\%), socioeconomic indicators continued to be determinants of stunting. The results of the two studies conducted by Laurentino et al and Vieira et $a l^{(11,12)}$ are in agreement with results published by Monteiro $e t$ al $^{(5)}$, who attributed the reduction in malnutrition in Brazil to the effects of four overriding factors: improvements in mothers' educational levels, increased family spending power and healthcare and basic sanitation; all of which are conditions that can also be observed in the Northeast region of $\mathrm{Brazil}^{(26)}$. In addition to their mothers' educational level, children and adolescents' nutritional status has also been linked with delays in their own schooling ("educational deficit": measured in terms of the number of years they would have been expected to have spent in education, less the number of years they had actually spent in education) ${ }^{(11,12)}$. This illustrates the influence that education has on the health-disease process, whether as a result of increasing understanding of childcare, in the case of mothers' education, or because the school environment is a protective factor, since it is active in forming nutritional and sanitary habits and can be a focus for encouraging young people to engage in physical activities ${ }^{(27)}$.

The state of basic sanitation, which is characterized by absence of water supply and public sewage in many of Brazil's less developed areas, can more than double the risk of growth deficit. Additionally, the lack of treated potable water can potentiate both infectious and parasitic diseases, with a direct impact on nutritional indicators ${ }^{(28)}$. Notwithstanding, 
despite the importance of basic sanitation, just $59.1 \%$ of Brazilian households are served by public sewers and once more the North and Northeast regions have the lowest rates of coverage. With regard to the public water supply, just $84.4 \%$ of households are connected and $11.4 \%$ of households do not have waste collection services ${ }^{(29)}$. These observations, in common with their impact on nutritional status and living conditions, make it clear that the subject is not given the priority it deserves on Brazil's political agenda.

The elevated percentage of stunting in rural populations also indicates a robust association between malnutrition and inadequate living conditions, for example, poor access to healthcare and low quality education, when compared with urban areas ${ }^{(11)}$. Economic policies designed to improve social equality have brought significant improvements in living conditions, with a consequent reduction in child malnutrition, and have closed the gap in nutritional status between children from the top and bottom fifths of the socioeconomic scale ${ }^{(5)}$. The report of increased risk for males and older age groups is in agreement with the results of recent studies conducted on the national level ${ }^{(6,7)}$, but no causal explanations for these findings have been confirmed or made explicit in other publications.

With regard to the variations in excess weight rates within regions, it is possible that these are related to different nutritional classification criteria used in different studies and/ or to the sampling frames used, since some studies were conducted with children enrolled at schools and others sampled households containing children and adolescents aged five to 19. Notwithstanding, the prevalence rates are above the cutoff for the reference population (2.3\%) according to the World Health Organization (WHO) ${ }^{(29)}$, which illustrates the severity of the problem an a national level.

Before its association with environmental and socioeconomic factors, obesity was impacted by the biological variables age and sex. Terres et $a l^{(16)}$ and Vieira et $a l^{(12)}$ both detected a reduction in excess weight as age increases, which is borne out by national Brazilian statistics. However, although Guedes et $a l^{(19)}$ also found a direct and significant association with age, when stratified by sex the behavior of different age groups was dramatically different. Whereas among the boys, the 15-to-18 age group has a $90 \%$ greater risk of obesity than the seven-to-ten age group, among the girls the proportion is similar for both age groups (at 5.7 and $6.1 \%$, respectively). It could be postulated that the differences between the studies mentioned above are due to the wide age range sampled (seven to 18 years) and the different sample sizes per sex or age group.
In those studies that did find a positive association with sex, it is possible that the higher prevalence rates among girls are caused by their increased sensitivity to sex hormones and to increased body fat deposition during adolescence. Additionally, during the same phase, girls engage in less physical activity than boys ${ }^{(30)}$. However, if results are broken down by type of school (public or private), boys studying at private schools are more likely to be obese than girls who study at private schools, suggesting that girls from higher social classes are more concerned about excess weight and body image ${ }^{(12)}$. More recent studies on the national level have provided evidence to support this hypothesis ${ }^{(6,7)}$, showing a trend for excess weight to be lower among girls from higher income brackets resident in richer areas of the country, which suggests that, at least for girls, the same inverse association observed in developed countries occurs here ${ }^{(31)}$.

Notwithstanding, overall in Brazil vulnerability to excess weight increases as socioeconomic status improves $^{(14,15,17,19-22,32)}$, which is almost always classified on the basis of domestic goods and the educational level of the head of the family. Where type of school (public or private) and location of residence are taken as proxies for socioeconomic status, it is found that living in areas that are more developed economically or studying at private school both increase the likelihood of excess weight ${ }^{(12,13,18,24)}$. Irrespective of type of school, educational deficit (falling behind) is also associated with overweight, although the trends are opposing, since educational deficit was a protective factor against overweight ${ }^{(12,16)}$.

Parents' educational level is another factor that has an impact on excess weight in children and adolescents. In Montes Claros, which is in the state of Minas Gerais, the risk of schoolchildren being overweight is significantly higher if the father or guardian spent nine years or more in education, while in Cuiabá, in Mato Grosso state, the children of mothers with a high educational level were three times more likely to be overweight ${ }^{(21,22)}$. In addition to their level of schooling, parents' nutritional status also impacts directly on their children's nutritional status ${ }^{(14,16,18,21)}$. Guimarães et al. observed a robust statistical association between parents' BMI, especially the mother's, and overweight among schoolchildren $^{(21)}$. Adjusted odds ratios (OR) were 7.27 for schoolchildren whose mothers were obese $(\mathrm{BMI} \geq 30)$ and 2.65 for those whose fathers were obese, compared with those whose parents had BMI $<25$. If one of the parents is obese, the likelihood that the child will develop obesity is $40 \%$ and if both parents are obese this likelihood can double ${ }^{(33)}$. 
To a certain extent, genetic factors can explain the direct relationship between the prevalence of overweight in the children of overweight parents. Notwithstanding, parents also serve as examples of the environmental determinants associated with excess weight, especially poor dietary habits and physical inactivity, and these behaviors are often imitated by their children ${ }^{(34)}$. Another issue relates to mothers' perceptions of their children's nutritional status, since, in general, mothers find it hard to recognize overweight, despite been concerned about their children's weight in the future and despite believing that normal weight children are healthier ${ }^{(35)}$.

The effect that number of siblings has on excess weight is due to the fact that being an only child increases maternal protectiveness, particularly in relation to the amount of food offered and also because the availability of food per capita increases as the number of residents decreases ${ }^{(22,36)}$. Another reference to the family unit relates to the variable number of marital unions: children whose mothers have only ever had one marital union were 2.53 times more likely to be overweight than those whose mothers had had two or more unions ${ }^{(22)}$.

With regard to leisure-time habits, time spent watching television contributes both to inactivity and to excessive energy intake, since, in addition to spending hours watching TV, viewers are exposed to advertisements for unhealthy foods ${ }^{(13,15,17,18,21)}$. Furthermore, these children and adolescents tend to eat more fast food and consume more sugary drinks than those who spend less time watching television ${ }^{(37)}$. The greater the number of hours per week ( $\geq 10$ hours) that children spend playing, the greater the association with reduction of excess weight ${ }^{(22)}$, irrespective of whether children play out around the home or at school, taking part in physical education lessons reduces the likelihood of developing obesity by $45 \%{ }^{(13)}$.

Other factors that affect the association between physical activity and excess weight are the distance from home to school and the means of transport utilized to cover this distance. Living less than $1 \mathrm{~km}$ from place of study increases the risk of overweight by 35 to $67 \%$ compared to those who live more than $10 \mathrm{~km}$ away. Additionally, going to school by car or public transport involves a greater risk of overweight than walking or cycling ${ }^{(22)}$.

The fact that so many of the overweight young people used the school cafeteria suggests they do not recognize the importance of the school meals provided for them and, in parallel, shows they are exposed to unhealthy food options, generally those with high energy density that are rich in fats and carbohydrates ${ }^{(22)}$. While the fact that young people diet (without proper guidance) and/or miss daily meals indicates that they are concerned with aesthetics and health, it may actually result in them snacking on foods with a high calorie density throughout the day ${ }^{(38)}$. It should be pointed out that the studies listed (Chart 2) did not analyze the dietary intake of the children and adolescents they studied, which is a barrier to the formation of hypotheses on lifestyle and nutritional status. Notwithstanding, it is known that inadequate dietary intake is one of the immediate causes of weight gain and is strongly influenced by family and socioeconomic status.

This review has shown that the determinants of nutritional status in children and adolescents are conditioned by socioeconomic and family patterns and behavioral characteristics related to lifestyle habits. In the case of stunting, it is educational level, income and basic sanitation that have the greatest impact. For excess weight, the strongest associations are with socioeconomic status, educational level of children and/or their parents and inactive lifestyles.

It is therefore evident that there is a need to intensify actions to monitor diet and nutrition in the age group described here, in parallel with achieving an equitable distribution of education and health services throughout the population. Finally, bearing in mind the number of studies already conducted in the South region of Brazil, it is suggested that investigations concentrate on nutritional disorders and associated factors in Brazil's North and Northeast regions.

\section{References}

1. Caballero B. Subnutrição e obesidade em países em desenvolvimento. Cad Est Desenv Soc em Debate 2005;2:10-3.

2. Batista Filho M, Batista LV. Transição alimentar/nutricional ou mutação antropológica? Cienc Cult 2010;62:26-30.

3. Monteiro CA, Benicio MH, Conde WL, Konno S, Lovadino AL, Barros AJ et al. Narrowing socioeconomic inequality in child stunting: the Brazilian experience, 1974-2007. Bull World Health Organ 2010;88:305-11.

4. Grantham-McGregor S, Landman J, Desai P. Child rearing in poor urban Jamaica. Child Care Health Dev 1983;9;57-71.

5. Monteiro CA, Benicio MH, Konno SC, Silva AC, Lima AL, Conde WL. Causes for the decline in child under-nutrition in Brazil, 1996-2007. Rev Saude Publica 2009;43:35-43.

6. Brasil. Ministério do Planejamento, Orçamento e Gestão; Instituto Brasileiro de Geografia e Estatística. Pesquisa de Orçamentos Familiares 2008-2009. 
Antropometria e estado nutricional de crianças, adolescentes e adultos no Brasil. Rio de Janeiro: IBGE; 2010.

7. Brasil. Ministério do Planejamento, Orçamento e Gestão; Instituto Brasileiro de Geografia e Estatística. Pesquisa de Orçamentos Familiares 2002-2003. Antropometria e análise do estado nutricional de crianças e adolescentes no Brasil. Rio de Janeiro: IBGE; 2006.

8. Miech RA, Kumanyika SK, Stettler N, Link BG, Phelan JC, Chang VW. Trends in the association of poverty with overweight among US adolescents, 19712004. JAMA 2006;295:2385-93.

9. World Health Organization. Global strategy on diet, physical activity and health. Food and Nutr Bull 2004;25:292-302.

10. Kain J, Vio F, Albala C. Obesity trends and determinant factors in Latin America. Cad Saude Publica 2003;19 (Suppl 1):S77-86.

11. Laurentino GE, Arruda IK, Raposo MC, Batista Filho M. Height deficit in school aged children: a multivariate analysis of possible risk factors, Pernambuco 1997. Arch Latinoam Nutr 2005;55:144-53.

12. Vieira MF, Araújo CL, Hallal PC, Madruga SW, Neutzling MB, Matijasevich $A$ et al. Nutritional status of first to fourth-grade students of urban schools in Pelotas, Rio Grande do Sul State, Brazil. Cad Saude Publica 2008;24:1667-74.

13. Tassitano RM, Barros MV, Tenório MC, Bezerra J, Hallal PC. Prevalence of overweight and obesity and associated factors among public high school students in Pernambuco State, Brazil. Cad Saude Publica 2009;25:2639-52.

14. Araújo CL, Dumith SC, Menezes AM, Hallal PC, Vieira MF, Madruga SW et al. Nutritional status of adolescents: the 11-year follow-up of the 1993 Pelotas (Brazil) birth cohort study. Cad Saude Publica 2010;26:1895-903.

15. Dutra CL, Araújo CL, Bertoldi AD. Prevalence of overweight in adolescentes: a population-based study in a southern Brazilian city. Cad Saude Publica 2006;22:151-62.

16. Terres NG, Pinheiro RT, Horta BL, Pinheiro KA, Horta LL. Prevalence and factors associated to overweight and obesity in adolescents. Rev Saude Publica 2006;40:627-33.

17. Rech RR, Halpern R, Costanzi CB, Bergmann ML, Alli LR, Mattos AP et al. Prevalence of obesity and overweight in schoolchildren aged 7 to 12 years from a city in southern Brazil. Rev Bras Cineantropom Desempenho Hum 2010;12:90-7.

18. Suñé FR, Dias-da-Costa JS, Olinto MT, Pattussi MP. Prevalence of overweight and obesity and associated factors among schoolchildren in a southern Brazilian city. Cad Saude Publica 2007;23:1361-71.

19. Guedes DP, Paula IG, Guedes JE, Stanganelli LC. Prevalência de sobrepeso e obesidade em crianças e adolescentes: estimativas relacionadas ao sexo, à idade e à classe socioeconômica. Rev Bras Educ Fis Esp 2006;20:151-63.

20. Netto-Oliveira ER, Oliveira AA, Nakashima AT, Rosaneli CF, Oliveira Filho $A$, Rechenchosky $L$ et al. Overweight and obesity in children of different socioeconomic levels. Rev Bras Cineantropom Desempenho Hum 2010;12:83-9.

21. Guimarães LV, Barros MB, Martins MS, Duarte EC. Factors associated with overweight in schoolchildren. Rev Nutr 2006;19:5-17.
22. Guedes DP, Miranda Neto JT, Almeida MJ, SilvaAJ. Impact of sociodemographic and behavioral factors on the prevalence of overweight and obesity in schoolchildren . Rev Bras Cineantropom Desemp Hum 2010;12:221-31.

23. Brasil. Associação Nacional de Empresas de Pesquisa. Critério de Classificação Econômica Brasil [cited 2010 Dec 17]. Available from: http:// www.datavale-sp.com.br/CCEB.pdf

24. Brasil LM, Fisberg M, Maranhão HS. Excess weight in children from Brazilian Northeast: difference between public and private schools. Rev Bras Saude Matern Infant 2007;7:405-12.

25. Gubert MB, Benício MH, Santos LM. Estimates of severe food insecurity in Brazilian municipalities. Cad Saude Publica 2010;26:1595-605.

26. Lima AL, Silva AC, Konno SC, Conde WL, Benicio MH, Monteiro CA. Causes of the accelerated decline in child undernutrition in Northeastern Brazil (19861996-2006). Rev Saude Publica 2010;44:17-27.

27. Monteiro CA, D'A Benicio MH, Conde WL, Popkin BM. Shifting obesity trends in Brazil. Eur J Clin Nutr 2000;54:342-6.

28. Monteiro CA, Benício MH, Freitas IC. Melhoria em indicadores de saúde associados à pobreza no Brasil dos anos 90: descrição, causas e impacto das desigualdades regionais. São Paulo: Nupens; 1997.

29. Brasil. Ministério da Saúde; Centro Brasileiro de Análise e Planejamento. Pesquisa Nacional de Demografia e Saúde da Criança e da Mulher: PNDS 2006: dimensões do processo reprodutivo e da saúde da criança [Série G. Estatística e Informação em Saúde]. Brasília: Ministério da Saúde; 2009.

30. Ferreira I, Van der Horst K, Wendel-Vos W, Kremers S, van Lenthe FJ, Brug $\mathrm{J}$. Environmental correlates of physical activity in youth - a review and update. Obes Rev 2007;8:129-54.

31. McLaren L. Socioeconomic status and obesity. Epidemiol Rev 2007;29:29-48.

32. Monteiro CA, Freitas IC. Secular trends in socioeconomic determinants of child health in S. Paulo city, Brazil (1984-1996). Rev Saude Publica 2000;34 (Suppl 6):8-12.

33. Krebs NF, Jacobson MS; American Academy of Pediatrics Committee on Nutrition. Prevention of pediatric overweight and obesity. Pediatrics 2003;112:424-30.

34. Whitaker RC, Wright JA, Pepe MS, Seidel KD, Dietz WH. Predicting obesity in young adulthood from childhood and parental obesity. $\mathrm{N}$ Engl J Med 1997;337:869-73.

35. Chuproski P, Mello DF. Mother's perception of their children's nutritional status. Rev Nutr 2009;22:929-36.

36. Stettler N, Tershakovec AM, Zemel BS, Leonard MB, Boston RC, Katz SH et al. Early risk factors for increased adiposity: a cohort study of African American subjects followed from birth to young adulthood. Am J Clin Nutr 2000;72:378-83.

37. French SA, Story M, Neumark-Sztainer D, Fulkerson JA, Hannan P. Fast food restaurant use among adolescents: associations with nutrient intake, food choices and behavioral and psychosocial variables. Int J Obes Relat Metab Disord 2001;25:1823-33.

38. Enes CC, Slater B. Obesity in adolescence and its main determinants. Rev Bras Epidemiol 2010;13:163-71. 